\title{
Chemical composition and antimicrobial activity of berry essential oil of Juniperus oxycedrus L. (Cupressaceae) grown wild in Republic of Macedonia
}

\author{
Floresha Sela ${ }^{1}$, Marija Karapandzova ${ }^{1 *}$, Gjose Stefkov ${ }^{1}$, Ivana Cvetkovikj ${ }^{1}$, \\ Elena Trajkovska-Dokikj ${ }^{2}$, Ana Kaftandzieva ${ }^{2}$, Svetlana Kulevanova ${ }^{1}$ \\ ${ }^{1}$ Institute of Pharmacognosy, Faculty of Pharmacy, University"Ss. Cyril and Methodius", Skopje, R. Macedonia \\ ${ }^{2}$ Institute of Microbiology and Parasitology, Faculty of Medicine, University"'Ss. Cyril and Methodius", \\ Skopje, R. Macedonia
}

Received: April 2013; Accepted: June 2013

\begin{abstract}
Chemical composition and antimicrobial activity of essential oil isolated from berries from 2 different samples of Juniperus oxycedrus L. (Cupressaceae), growing wild in Republic of Macedonia was investigated. Performing GC/FID/MS analysis, one hundred components were identified, representing $96.0-98.95 \%$ of the oil. The major components were $\alpha$-pinene (22.54- 27.12\%), myrcene (11.26- $15.13 \%$ ) and limonene (2.78-18.06\%). Antimicrobial screening of the $J$. oxycedrus essential oils was made by disc diffusion and broth dilution method against 16 bacterial isolates of Gram positive and Gram negative bacteria and one strain of Candida albicans. The most sensitive bacteria was Haemophilus influenzae $(\mathrm{MIC}=125 \mu \mathrm{l} / \mathrm{ml})$. The essential oils showed moderate antimicrobial activity against Streptococcus pneumoniae, Staphylococcus aureus, Streptococcus agalactiae, Streptococcus pyogenes, Corynebacterium spp., Escherichia coli and Campilobacter jejuni (MIC $>500 \mu \mathrm{l} / \mathrm{ml}$ ) and no activity against Candida albicans, Staphylococcus epidermidis, Acinetobacter spp., Salmonella enteritidis, Shigella flexnery, Klebsiella pneumonia, Pseudomonas aeruginosa, Enterococcus and Proteus mirabilis.
\end{abstract}

Keywords: Juniperus oxycedrus, berry essential oil, oil composition, GC/FID/MS, antimicrobial activity.

\section{Introduction}

Juniperus oxycedrus L. (Cupressaceae) is a hardy spreading plant, that vary in size from a low shrub to a tree of about $6 \mathrm{~m}$. The leaves are tiny, narrow and prickly and are reason for people' name of the plant:"Prickly Juniper". The cones are yellow and rounded, and the fruits are berry-like, growing in clusters, and black when ripe. The plant is known as Cade juniper as well, mainly because of the oil that is obtained through destructive distillation of the wood. Cade oil is dark, aromatic oil with a strong smoky

\footnotetext{
* Marija Karapandzova@ff.ukim.edu.mk; marijakarapandzova@yahoo.com
}

smell which is used in some cosmetics and traditional skin treatment drugs, as well as an incense (Lamnauer, 2005).

$J$. oxycedrus is known as Mediterranean equivalent of the common juniper, native across the Mediterranean region from Morocco and Portugal, southern France and east to Iran, Lebanon and Israel. It grows on rocky sites from sea level up to $1600 \mathrm{~m}$ altitude. Among J. oxycedrus interesting subspecies are $J$. oxycedrus var. badia H.Gay (syn. J. oxycedrus subsp. badia (H.Gay) Debeaux), distinguished on the basis of larger cones and described from northern Algeria, but also reported for Portugal and Spain (Salido et al., 2002; Velasco-Negueruela et al., 2003) and $J$. oxycedrus subsp. macrocarpa (S. et Sm.) Ball., confined to Mediterranean coastal sands, which differs in the broader 
leaves 2-3 mm wide and larger cones (Stassi et al., 1995).

Aromatical oils from different parts of $J$. oxycedrus have been used since antiquity for fragrance, flavoring, medicinal, antibacterial, insecticidal, and cosmetic purposes. In folk medicine, they have been recommended as a mouth analgesic and for stomach disorders. Berries of this plant are used as a spice, particularly in European cuisine, and essential oil is used for production of beverages such as gin, to which the oil gave distinguishing flavor. The composition of leaf essential oil of J. oxycedrus from Morocco (Derwich and Chabir, 2011), Tunisia (Medini et al., 2010), Greece (Adams et al., 1999), Corsica (Boti et al., 2006), and Allgeria (Dob et al., 2006) has been reported in varying details. The oil is characterized by large amount of $\alpha$-pinene followed by smaller amounts of sabinene, limonene, $\beta$-pinene, caryophyllene oxide and myrcene (Derwich et al., 2010; Derwich and Chabir, 2011; Adams et al., 1999). Berry essential oil of J. oxycedrus was examined in Italy and similar composition to that of the leaf essential oil was found with predominant amounts of $\alpha$-pinene followed by smaller amounts of $\beta$-pinene, $\delta$-3-carene, sabinene, myrcene, $\alpha$-phellandrene, limonene and germacrene D (Angioni et al., 2003). Additionally, authors found that ripeness of the berries does not have large influence on the oil composition. Boti et al. (2006) found $\alpha$-pinene, $\beta$-phellandrene and $\delta$-3-carene as the most abundant constituents in the berry essential oil from Corsica. The berry essential oil of $J$. oxycedrus ssp. badia from Spain contained $\alpha$-pinene and myrcene as the predominant components (Velasco-Negueruela et al., 2003), while the oil of J. oxycedrus ssp. macrocarpa contained $\alpha$-pinene, germacrene D, myrcene, abietadiene and cis-calamenene as major constituents (Medini et al., 2012).

J. oxycedrus essential oil possess broad spectrum of biological activities: antioxidant (Loizzo et al. 2007), antimicrobial (Angioni et al., 2003; Medini et al., 2012), antifungal (Cavaleiro et al., 2006), wound healing (Tumen et al., 2012), insecticidal (Athanassiou et al., 2013), herbicidal (Ismail et al., 2011), etc. The oil with predominated content of $\alpha$-pinene and $\beta$-myrcene possesses antiviral activity against HIV-1 (Loizzo, 2008). Antibacterial and antifungal activity against different pathological strains that grow on food makes possible use of $J$. oxycedrus essential oil as food preservative (Stassi at al. 1996).

In Macedonian flora, only J. oxycedrus L. subsp. oxycedrus is present (Micevski, 1989). This species is spread throughout the whole territory of Republic of Macedonia, except on very high altitudes on mountains in the continental part. Up to now, J. oxycedrus was not chemically investigated and no testing of possible biological and pharmacological activities was performed. Therefore the aim of the present study was analysis of chemical composition of berry essential oil of this plant and evaluation of its antimicrobial activity.

\section{Material and methods}

\section{Plant materials}

The terminal twigs with berries were collected from two different localities in R. Macedonia: Velestovo village near Ohrid Lake and Vodno Mtn., near Skopje, in late autumn 2010 and 2012. Plant identity was verified as Juniperus oxycedrus L., and herbarium voucher specimen $\mathrm{N}^{\circ}$ JO-1/10, No JO-1/12, were deposited at the Department of Pharmaceutical Botany, Institute of Pharmacognosy, Faculty of Pharmacy, Skopje, R. Macedonia.

The plant material was dried at room temperature. Just before essential oil isolation, the berries were separated from leaves and branches and minced properly.

\section{Chemicals}

Dimethylsulfoxide was purchased from Sigma-Aldrich (Steinheim, Germany), sodium chloride and anhydrous sodium sulfate from Merck (Darmstadt, Germany) and from Kemica (Zagreb, Croatia), respectively, while xylene was purchased from Alkaloid (Skopje, R. Macedonia).

\section{Essential oil isolation}

Essential oil isolation from plant material was made by steam distillation in special all-glass Clevenger type apparatus. For that purpose, $20 \mathrm{~g}$ of minced plant material was distilled for 4 hours. After isolation, anhydrous sodium sulfate was added to remove residual water from the oil. The essential oil yield was calculated on dried plant material and was expressed in $\mathrm{ml} / \mathrm{kg}$. For GC/FID/MS analysis, the essential oil was dissolved in xylene to obtain $1 \mu \mathrm{l} / \mathrm{ml}$ oil solution.

\section{Gas chromatography (GC) and gas chromatography/mass spectrometry (GC/MS)}

Essential oil samples were analyzed on Agilent 7890A Gas Chromatography system equipped with FID detector and Agilent 5975C Mass Quadrupole detector as well as capillary flow technology which enables simultaneous analysis of the samples on both detectors. For that purpose, HP-5ms capillary column $(30 \mathrm{~m} \times 0.25 \mathrm{~mm}$, film thickness $0.25 \mu \mathrm{m}$ ) was used. Operating conditions were as follows: oven temperature at $60{ }^{\circ} \mathrm{C}(5 \mathrm{~min}), 1{ }^{\circ} \mathrm{C} / \mathrm{min}$ to 80 ${ }^{\circ} \mathrm{C}(2 \mathrm{~min})$ and $5{ }^{\circ} \mathrm{C} / \mathrm{min}$ to $280{ }^{\circ} \mathrm{C}(5 \mathrm{~min})$; helium as carrier gas at a flow rate of $1 \mathrm{ml} / \mathrm{min}$; injector temperature 260 ${ }^{\circ} \mathrm{C}$ and that of the FID $270{ }^{\circ} \mathrm{C} .1 \mu \mathrm{l}$ of each sample was injected at split ratio 1:1. The mass spectrometry conditions were: ionization voltage $70 \mathrm{eV}$, ion source temperature 230 ${ }^{\circ} \mathrm{C}$, transfer line temperature $280{ }^{\circ} \mathrm{C}$ and mass range from 50 - $500 \mathrm{Da}$. The MS was operated in scan mode. 


\section{Identification of the components}

Identification of the components present in essential oils was made by comparing mass spectra of components in essential oils with those from Nist, Wiley and Adams mass spectra libraries, by AMDIS (Automated Mass Spectral Deconvolution and Identification System) and by comparing literature and estimated Kovat's (retention) indices that were determined using mixture of homologous series of normal alkanes from $\mathrm{C}_{9}$ to $\mathrm{C}_{25}$ in hexane, under the same above mentioned conditions.

The percentage ratio of essential oils components was computed by the normalization method of the GC/FID peak areas without any correction factors.

\section{Antimicrobial activity: microbial strains and cultures}

16 bacterial isolates representing both Gram positive and Gram negative bacteria and one strain of Candida albicans were used for antimicrobial screening. Five isolates were standard strains (Staphylococcus aureus ATCC 29213, Escherichia coli 25927, Klebsiella pneumoniae ATCC 700603, Pseudomonas aeruginosa ATCC 27853 and Candida albicans ATCC 10231). The remaining 12 bacterial strains (Staphylococcus epidermidis, Enterococcus, Streptococcus pyogenes, Streptococcus agalactiae, Streptococcus pneumoniae, Haemophylus influenzae, Proteus mirabilis, Salmonella enteritidis, Salmonella enteritidis, Shigella flexneri, Campylobacter jejuni, and Acinetobacter spp.) were clinical isolates provided from the Institute of Microbiology and Parasitology, Faculty of Medicine, Skopje, R. Macedonia.

A nutrient (Mueller Hinton) agar from Merck (Darmstadt, Germany), blood agar (Oxoid, Basingstoke, UK) and Sabouraund agar (bioMerieux, Durham, NC) were used for growing of the microbial strains.

\section{Disc diffusion method}

Disc diffusion method was used for screening the antimicrobial activity of all essential oils in order to determine the growth inhibition zones of studied microorganisms that occur around certain essential oil. In this regard, microorganisms were suspended in sterile broth with turbidity corresponding to 0.5 and $1 \mathrm{Mc}$ Farland (approximate by $10^{7}$ $10^{8} \mathrm{CFU} / \mathrm{ml}$ ) for all bacteria and for Candida albicans, respectively. The microbial suspensions were streaked over the surface of the agar media using a sterile cotton swabs to ensure uniform inoculation. After inoculation of microorganisms, discs of $6 \mathrm{~mm}$ in diameter were made at wellspaced intervals. They were filled with $85 \mu \mathrm{l}$ of $50 \%$ solutions of essential oils in dimethylsulfoxide (DMSO, Sigma-Aldrich, Germany) and one disc was filled only with DMSO as a control. The plates were incubated at $37^{\circ} \mathrm{C}$, aerobically for 24 hours. The growth inhibition zones were measured after incubation of the isolates under their optimal growth conditions and were ranged between $6 \mathrm{~mm}$ and
$30 \mathrm{~mm}$ in diameter. The antimicrobial activity was determined according to the diameters of the inhibition zones (0-14 mm resistant - R, 14-19 mm moderate susceptible $\mathrm{M}$ and 19-30 susceptible microorganisms - S).

\section{Broth dilution method}

This method was used in order to determine minimal inhibitory concentration (MIC) of the particular essential oil (50\% solution in DMSO) that had revealed antimicrobial activity by disc diffusion method. For that purposes, $25 \mu \mathrm{l}$ of those essential oils were diluted in equal quantities of $0.9 \%$ sodium chloride solution, to make them with the concentration of $25 \%$. This concentration was decreased five times, subsequently, by adding $25 \mu \mathrm{l}$ of each bacterial or fungal suspension, thus the final concentrations were: $12.5 \%, 6.2 \%, 3.1 \%, 1.5 \%$ and $0.7 \%$ or $125 \mu \mathrm{l} / \mathrm{ml}, 62 \mu \mathrm{l} / \mathrm{ml}$, $31 \mu \mathrm{l} / \mathrm{ml}, 15 \mu \mathrm{l} / \mathrm{ml}$ and $7 \mu \mathrm{l} / \mathrm{ml}$, respectively. $15 \mu \mathrm{l}$ of each bacterial or fungal suspensions with these particular concentrations were inoculated on solid media (Mueller-Hinton agar, blood agar, Sabouraund agar), depending on the type of microorganism. The growth of any microorganism was evaluated after its incubation under the optimal growth conditions. The lowest concentration of essential oil which was able to inhibit the growth of the particular microorganism was considered as its minimal inhibitory concentration (MIC).

\section{Results and discussion}

The obtained essential oils of $J$. oxycedrus were transparent, agile, light yellowish liquids with specific and very strong turpentine odor. Using GC/FID/MS a total of 100 components were identified, representing $96.01-98.95 \%$ of the oils. Among different classes of components, the most abundant fraction for Velestovo and Vodno oils were the monoterpene hydrocarbons (MH) $(59.23 \%$ and $60.43 \%$, respectively), followed by the sesquiterpene hydrocarbons (SH) $(21.58 \%$ and $28.72 \%$, respectively) (Table 1$)$. Both samples of essential oils, contained smaller amounts of oxygen-containing monoterpenes (OM) $(5.63 \%$ and $3.67 \%$, respectively) as well as oxygen-containing sesquiterpenes (OS) (9.13\% and 5.75\%, respectively) (Table 1).

Chemical analysis of the berry essential oil of $J$. oxycedrus showed presence of tree main components: $\alpha$-pinene (22.54\% and $27.12 \%), \beta$-myrcene (11.26\% and $15.13 \%)$ and limonene $(18.06 \%$ and $2.78 \%)$. Additionally, $\beta$-pinene $(2.60 \%$ and $3.14 \%)$, trans-caryophyllene $(6.18 \%$ and $2.67 \%), \alpha$-humulene $(4.65 \%$ and $2.68 \%$ ), and $\delta$-cadinene (4.16\% and $2.23 \%$ for Velestovo and Vodno, respectively) were determined in smaller amounts. Larger amounts of germacrene D (11.50\%) were found only in the sample from Vodno. 
Table 1. Chemical composition (\%) of Juniperus oxycedrus berry essential oils

\begin{tabular}{|c|c|c|c|c|c|}
\hline No. & Components & KIL & KIE & Velestovo 2010 & Vodno 2012 \\
\hline 1 & Tricyclene & 921 & 938.9 & 0.02 & 0.03 \\
\hline 2 & $\alpha$-Thujene & 931 & 940.8 & 0.26 & 0.75 \\
\hline 3 & $\alpha$-Pinene & 932 & 949.4 & 22.54 & 27.12 \\
\hline 4 & Camphene & 946 & 955.6 & 0.45 & 0.26 \\
\hline 5 & Verbenene & 961 & 966.9 & - & 0.04 \\
\hline 6 & Sabinene & 969 & 975.1 & 1.15 & 9.17 \\
\hline 7 & $\beta$-Pinene & 974 & 976.2 & 2.60 & 3.14 \\
\hline 8 & $\beta$-Myrcene & 988 & 990.6 & 11.26 & 15.13 \\
\hline 9 & $\alpha$-Phellandrene & 1002 & 997.1 & - & 0.05 \\
\hline 10 & $\delta^{3}$-Carene & 1008 & 1001.5 & - & 0.13 \\
\hline 11 & $\alpha$-Terpinene & 1014 & 1007.2 & 0.61 & 0.27 \\
\hline 12 & p-Cymene & 1020 & 1014.3 & 0.13 & 0.09 \\
\hline 13 & Limonene & 1024 & 1018.6 & 18.06 & 2.78 \\
\hline 14 & $\beta$-Phellandrene & 1025 & 1019.9 & - & - \\
\hline 15 & $Z$ - $\beta$-Ocimene & 1032 & 1037.1 & - & 0.02 \\
\hline 16 & $E$ - $\beta$-Ocimene & 1044 & 1037.3 & - & 0.04 \\
\hline 17 & $\gamma$-Terpinene & 1054 & 1046.4 & 1.14 & 0.54 \\
\hline 18 & cis-Sabinene hydrate & 1065 & 1054.2 & - & 0.13 \\
\hline 19 & Terpinolene & 1086 & 1076.3 & 1.03 & 0.94 \\
\hline 20 & Linalool & 1095 & 1091.2 & 0.69 & 0.77 \\
\hline 21 & 2-Methyl butyl isovalerate & 1103 & 1095.6 & 0.22 & - \\
\hline 22 & cis-p-Menth-2-en-1-ol & 1118 & 1114.2 & - & 0.05 \\
\hline 23 & $\alpha$-Campholenal & 1122 & 1121.0 & - & 0.03 \\
\hline 24 & trans-Pinocarveol & 1135 & 1135.4 & - & 0.03 \\
\hline 25 & trans-p-Menth-2-en-1-ol & 1136 & 1138.2 & - & 0.05 \\
\hline 26 & trans-Verbenol & 1140 & 1143.9 & - & 0.06 \\
\hline 27 & Citronelall & 1148 & 1155.0 & - & 0.02 \\
\hline 28 & $\beta$-Pinene oxide & 1154 & 1159.4 & - & 0.03 \\
\hline 29 & Borneol & 1165 & 1163.2 & 0.14 & 0.04 \\
\hline 30 & $p$ - Menth-1,5-dien-8-ol & 1166 & 1166.2 & - & 0.02 \\
\hline 31 & Terpinen-4-ol & 1174 & 1162.3 & 1.60 & 1.13 \\
\hline 32 & $p$-Cymene-8-ol & 1179 & 1184.4 & - & 0.04 \\
\hline 33 & $\alpha$-Terpineol & 1186 & 1184.6 & 0.60 & 0.18 \\
\hline 34 & Myrtenol & 1194 & 1188.5 & - & 0.05 \\
\hline 35 & Methyl chavicol & 1195 & 1190.4 & - & 0.03 \\
\hline 36 & Verbenone & 1204 & 1197.4 & - & 0.04 \\
\hline 37 & endo-Fenchyl acetate & 1218 & 1207.5 & - & 0.02 \\
\hline 38 & $\beta$-Citronellol & 1223 & 1220.1 & 0.30 & 0.15 \\
\hline 39 & trans -Chrysanthenyl acetate & 1235 & 1224.6 & - & 0.05 \\
\hline 40 & Thymol methyl ether & 1232 & 1225.3 & - & - \\
\hline 41 & Neral & 1235 & 1232.2 & - & 0.08 \\
\hline 42 & Hexyl isovalerate & 1241 & 1232.6 & 0.05 & - \\
\hline 43 & Isoamyl hexanoate & 1246 & 1240.9 & 0.08 & - \\
\hline 44 & Geraniol & 1249 & 1247.3 & - & 0.06 \\
\hline 45 & cis-Myrtanol & 1250 & 1249.2 & - & $\operatorname{tr}$ \\
\hline 46 & Methyl citronellate & 1257 & 1252.7 & - & 0.05 \\
\hline 47 & Geranial & 1264 & 1261.8 & - & 0.07 \\
\hline 48 & Bornyl acetate & 1284 & 1261.6 & 0.09 & 0.25 \\
\hline 49 & trans-Sabinyl acetate & 1289 & 1279.6 & 1.29 & - \\
\hline 50 & 2-Undecanone & 1293 & 1282.3 & - & 0.07 \\
\hline 51 & Terpinen-4-ol-acetate & 1299 & 1286.9 & - & 0.02 \\
\hline 52 & Myrtenil acetate & 1324 & 1310.6 & - & 0.12 \\
\hline 53 & $\delta$-Elemene & 1335 & 1322.4 & 0.04 & 0.22 \\
\hline 54 & $\alpha$-Cubebene & 1345 & 1335.3 & 0.09 & 0.59 \\
\hline 55 & Citronellyl acetate & 1350 & 1339.2 & - & 0.08 \\
\hline 56 & Dihydro carveol acetate & 1356 & 1350.0 & - & 0.03 \\
\hline
\end{tabular}




\begin{tabular}{|c|c|c|c|c|c|}
\hline No. & Components & KIL & KIE & Velestovo 2010 & Vodno 2012 \\
\hline 57 & $\alpha$-Ylangene & 1373 & 1356.7 & - & 0.02 \\
\hline 58 & $\alpha$-Copaene & 1374 & 1361.5 & 0.20 & 0.58 \\
\hline 59 & Geranyl acetate & 1379 & 1368.9 & - & 0.23 \\
\hline 60 & $\beta$-Bourbonene & 1387 & 1369.9 & 0.03 & - \\
\hline 61 & $\beta$-Elemene & 1389 & 1378.2 & 0.23 & 2.09 \\
\hline 62 & Longipinene & 1400 & 1384.6 & - & - \\
\hline 63 & Sibirene & 1400 & 1386.8 & - & 0.31 \\
\hline 64 & $\beta$-Longifolene & 1407 & 1390.2 & - & $\operatorname{tr}$ \\
\hline 65 & $\alpha$-cis-Bergamotene & 1411 & 1397.9 & - & 0.01 \\
\hline 66 & trans-(E)-Caryophyllene & 1417 & 1404.0 & 6.18 & 2.67 \\
\hline 67 & $\beta$-Copaene & 1430 & 1413.0 & 0.11 & 0.35 \\
\hline 68 & $\gamma$-Elemene & 1434 & 1418.3 & 0.45 & 2.08 \\
\hline 69 & $\alpha$-Guaiene & 1437 & 1419.2 & 0.07 & - \\
\hline 70 & 6,9-Guaidiene & 1442 & 1424.6 & 0.08 & \\
\hline 71 & Unknown & 1 & 1435.6 & - & 0.19 \\
\hline 72 & $\alpha$-Humulene & 1454 & 1439.3 & 4.65 & 2.68 \\
\hline 73 & cis-Muurola-4,(14),5-diene & 1465 & 1448.0 & $\operatorname{tr}$ & 0.14 \\
\hline 74 & Germacrene D & 1484 & 1471.5 & 1.89 & 11.50 \\
\hline 75 & $\beta$-Selinene & 1485 & 1473.8 & 0.11 & $\operatorname{tr}$ \\
\hline 76 & Bicyclogermacrene & 1494 & 1501.7 & 0.20 & - \\
\hline 77 & $\alpha$-Muurolene & 1500 & 1483.7 & 1.07 & 1.71 \\
\hline 78 & $\gamma$-Cadinene & 1513 & 1496.9 & 1.16 & 0.69 \\
\hline 79 & $\delta$-Cadinene & 1522 & 1506.8 & 4.16 & 2.23 \\
\hline 80 & trans-Cadina-1,4-diene & 1533 & 1514.7 & 0.15 & 0.12 \\
\hline 81 & $\alpha$-Cadinene & 1537 & 1519.9 & - & 1.71 \\
\hline 82 & Elemol & 1549 & 1532.1 & 0.10 & 0.19 \\
\hline 83 & Unknown & 1 & 1537.4 & 0.42 & 0.09 \\
\hline 84 & Germacrene B & 1559 & 1543.3 & 0.41 & 1.73 \\
\hline 85 & Germacrene D-4-ol & 1574 & 1560.7 & - & 1.37 \\
\hline 86 & Spathulenol & 1577 & 1563.0 & 0.06 & $\operatorname{tr}$ \\
\hline 87 & Caryophyllene oxide & 1581 & 1593.2 & 1.63 & 0.17 \\
\hline 88 & Humulene epoxide II & 1608 & 1593.6 & 1.80 & 0.17 \\
\hline 89 & 1,10-di-epi-Cubenol & 1618 & 1596.5 & $\operatorname{tr}$ & $\operatorname{tr}$ \\
\hline 90 & Junenol & 1618 & 1602.4 & 0.17 & $\operatorname{tr}$ \\
\hline 91 & 1-epi-Cubenol & 1627 & 1610.7 & 0.26 & 0.25 \\
\hline 92 & $\gamma$-Eudesmol & 1630 & 1613.9 & 0.17 & - \\
\hline 93 & $\tau$-Murolol & 1640 & 1624.7 & 1.55 & 0.88 \\
\hline 94 & $\alpha$-Muurolol & 1645 & 1613.4 & 0.38 & $\operatorname{tr}$ \\
\hline 95 & $\alpha$-Cadinol & 1653 & 1638.8 & 2.60 & 1.16 \\
\hline 96 & Cadalene & 1675 & 1657.1 & $\operatorname{tr}$ & - \\
\hline 97 & Abieta-8,12-diene & 2022 & 2004.0 & $\operatorname{tr}$ & $\operatorname{tr}$ \\
\hline 98 & Abietatriene & 2054 & 2024.8 & $\operatorname{tr}$ & $\operatorname{tr}$ \\
\hline 99 & Abietadiene & 2080 & 2172.8 & $\operatorname{tr}$ & $\operatorname{tr}$ \\
\hline \multirow[t]{6}{*}{100} & Sandarocopimarinal & 2184 & 2172.5 & $\operatorname{tr}$ & $\operatorname{tr}$ \\
\hline & Total & & & 96.01 & 98.95 \\
\hline & Monoterpene hydrocarbons (MH) & & & 59.23 & 60.43 \\
\hline & Oxygen containing monoterpenes (OM) & & & 5.63 & 3.67 \\
\hline & Sesquiterpene hydrocarbons (SH) & & & 21.58 & 28.72 \\
\hline & Oxygen containing sesquiterpenes (OS) & & & 9.13 & 5.75 \\
\hline
\end{tabular}

KIL - Kovat's (retention) index - literature data (Adams, 2007); KIE - Kovat's (retention) index experimentally determined (AMDIS); $(-)$ - not found, $\operatorname{tr}-\operatorname{traces}<0.02$. 
Table 2. Antimicrobial activity of the berry essential oil of Juniperus oxycedrus.

\begin{tabular}{lccc}
\hline \hline Microorganism & & Velestovo & Vodno \\
\hline Streptococcus & $\mathrm{DD}$ & $\mathrm{M}$ & $\mathrm{R}$ \\
pneumoniae & $\mathrm{MIC}$ & $>500$ & $\mathrm{n} . \mathrm{m}$. \\
Staphylococcus & $\mathrm{DD}$ & $\mathrm{M}$ & $\mathrm{R}$ \\
aureus & $\mathrm{MIC}$ & $>500$ & $\mathrm{n} . \mathrm{m}$. \\
Staphylococcus & $\mathrm{DD}$ & $\mathrm{R}$ & $\mathrm{R}$ \\
epidermidis & $\mathrm{MIC}$ & $\mathrm{n} . \mathrm{m}$. & $\mathrm{n} . \mathrm{m}$. \\
Streptococcus & $\mathrm{DD}$ & $\mathrm{M}$ & $\mathrm{R}$ \\
agalactiae & $\mathrm{MIC}$ & $>500$ & $\mathrm{n} . \mathrm{m}$. \\
Streptococcus & $\mathrm{DD}$ & $\mathrm{M}$ & $\mathrm{M}$ \\
pyogenes & $\mathrm{MIC}$ & $>500$ & $>500$ \\
Enterococcus & $\mathrm{DD}$ & $\mathrm{R}$ & $\mathrm{R}$ \\
& $\mathrm{MIC}$ & $\mathrm{n} . \mathrm{m}$. & $\mathrm{n} . \mathrm{m}$. \\
Corynebacterium spp. & $\mathrm{DD}$ & $\mathrm{M}$ & $\mathrm{R}$ \\
& $\mathrm{MIC}$ & $>500$ & $\mathrm{n} . \mathrm{m}$. \\
Haemophilus & $\mathrm{DD}$ & $\mathrm{S}$ & $\mathrm{S}$ \\
influenzae & $\mathrm{MIC}$ & 125 & 125 \\
Acinetobacter spp. & $\mathrm{DD}$ & $\mathrm{R}$ & $\mathrm{R}$ \\
& $\mathrm{MIC}$ & $\mathrm{n} . \mathrm{m}$. & $\mathrm{n} . \mathrm{m}$. \\
Escherichia coli & $\mathrm{DD}$ & $\mathrm{R}$ & $\mathrm{M}$ \\
& $\mathrm{MIC}$ & $\mathrm{n} . \mathrm{m}$. & $>500$ \\
Salmonella enteritidis & $\mathrm{DD}$ & $\mathrm{R}$ & $\mathrm{R}$ \\
& $\mathrm{MIC}$ & $\mathrm{n} . \mathrm{m}$. & $\mathrm{n} . \mathrm{m}$. \\
Shigella flexneri & $\mathrm{DD}$ & $\mathrm{R}$ & $\mathrm{R}$ \\
& $\mathrm{MIC}$ & $\mathrm{n} . \mathrm{m}$. & $\mathrm{n} . \mathrm{m}$. \\
Campylobacter jejuni & $\mathrm{DD}$ & $\mathrm{M}$ & $\mathrm{M}$ \\
& $\mathrm{MIC}$ & $>500$ & $>500$ \\
Klebsiella & $\mathrm{DD}$ & $\mathrm{R}$ & $\mathrm{R}$ \\
pneumoniae & $\mathrm{MIC}$ & $\mathrm{n} . \mathrm{m}$. & $\mathrm{n} . \mathrm{m}$. \\
Pseudomonas & $\mathrm{DD}$ & $\mathrm{R}$ & $\mathrm{R}$ \\
aeruginosa & $\mathrm{MIC}$ & $\mathrm{n} . \mathrm{m}$. & $\mathrm{n} . \mathrm{m}$. \\
Proteus mirabilis & $\mathrm{DD}$ & $\mathrm{R}$ & $\mathrm{R}$ \\
& $\mathrm{MIC}$ & $\mathrm{n} . \mathrm{m}$. & $\mathrm{n} . \mathrm{m}$. \\
Candida albicans & $\mathrm{DD}$ & $\mathrm{R}$ & $\mathrm{R}$ \\
& $\mathrm{MIC}$ & $\mathrm{n} . \mathrm{m}$. & $\mathrm{n} . \mathrm{m}$. \\
\hline & & & \\
& & & \\
& & &
\end{tabular}

DD - Disc diffusion (zone of inhibition including the diameter of disc $6 \mathrm{~mm}$ ), $\mathrm{R}=$ resistant with zone of inhibition 0-14 $\mathrm{mm}, \mathrm{M}$ $=$ moderate susceptible with zone of inhibition $14-19 \mathrm{~mm}$ and $\mathrm{S}$ = susceptible microorganism with zone of inhibition 19-30 mm); MIC - minimum inhibitory concentration $(\mu \mathrm{l} / \mathrm{ml})$; n.m. - not measured.

Similar composition of the berry essential oil was found for the Spanish $J$. oxycedrus ssp. badia with $\alpha$-pinene $(59.8-61.5 \%)$ and myrcene (18.5-18.6\%) as major constituents of the oil (Velasco-Negueruela et al., 2003). Furthermore, in unripe berries, Salido et al. (2002) found essential oil rich with $\alpha$-pinene $(65 \%)$ and smaller amounts of myrcene, limonene, germacrene D and $\gamma$-muurolene. Medini et al. (2011) reported that the amounts of $\alpha$-pi- nene, germacrene D, myrcene, abietadiene and cis-calamenene vary according to the phonological stage of $J$. oxycedrus ssp. macrocarpa. Berry essential oil of $J$. oxycedrus ssp. macrocarpa from Greece contained $63.03 \%$ of $\alpha$-pinene (Stassi et al., 1995). Comparing to the leaf essential oil composition of $J$. oxycedrus, similarities could be found as the leaf essential oil contain $\alpha$-pinene as the most abundant constituent (Derwich et al., 2010; Derwich et al., 2011; Boti et al., 2006; Salido et al., 2002; Adams et al., 1999; Stassi et al., 1995; Medini et al., 2010; Angioni et al., 2003).

Antimicrobial screening of the essential oils was made by disc diffusion and broth dilution method against 16 bacterial isolates of Gram positive and Gram negative bacteria and one strain of Candida albicans. The most sensitive bacteria to antimicrobial effects of Juniperus oxycedrus berry essential oils was Haemophilus influnzae (MIC $=125 \mu \mathrm{l} / \mathrm{ml})($ Table 2$)$.

The berry essential oil showed moderate antimicrobial activity against Streptococcus pneumoniae, Staphylococcus aureus, Streptococcus agalactiae, Streptococcus pyogenes, Corynebacterium spp., Escherichia coli and Campilobacter jejuni with MIC $>500 \mu \mathrm{l} / \mathrm{ml}$. No activity against Candida albicans, Staphylococcus epidermidis, Acinebacter spp., Salmonella enteritidis, Shigella flexnery, Klebsiella pneumonia, Pseudomonas aeruginosa, Enterococcus and Proteus mirabilis was found.

According to literature data, essential oils of $J$. oxycerdrus, J. phoenicea and J. communis were tested against Candida albicans, Staphylococcus aureus, Escherichia coli and Pseudomonas aeruginosa. The results obtained led to a non-significant inhibitory effect, although essential oil of $J$. phoenicea and leaf oil of $J$. oxycerdrus exhibited rather good or weak activity against Candida albicans and Staphylococcus aureus (Angioni et al., 2003). The study of the antimicrobial activity of leaf essential oil of J. oxycedrus from Tunisia showed that Escherichia coli was found to be extremely resistant to this oil while Staphylococcus aureus was the most sensitive strain with MIC ranged from 600 to $650 \mu \mathrm{g} / \mathrm{ml}$ (Medini et al., 2012). J. oxycerdrus leaf essential oil provided to be an emergent alternative as antifungal agent against dermatophyte strains. $\delta$-3-carene was shown to be a fundamental compound for this activity (Cavaliero et al., 2006).

\section{Conclusion}

The major components in the essential oil of two samples of berries of Juniperus oxycedrus L. (Cupressaceae), growing wild in R. Macedonia were $\alpha$-pinene, myrcene and limonene. $\beta$-pinene, caryophyllene, $\alpha$-humulene and $\delta$-cadinene were determinate in smaller amounts while larger amount of germacrene $\mathrm{D}$ was found only in one sample of the oil. Antimicrobial screening of the essential oils showed that the most sensitive bacteria was Haemophilus influenzae $(\mathrm{MIC}=125 \mu \mathrm{l} / \mathrm{ml})$. The $J$. oxycedrus essential 
oil showed moderate antimicrobial activity against Streptococcus pneumoniae, Staphylococcus aureus, Streptococcus agalactiae, Streptococcus pyogenes, Corynebacterium spp., Escherichia coli and Campilobacter jejuni (MIC > $500 \mu \mathrm{l} / \mathrm{ml}$ ) and no activity against other investigated bacteria and Candida albicans.

\section{References}

Adams, R., Altarejos, J., Fermandez, C., Camacho, A., 1999. The leaf essential oils and taxonomy of Juniperus oxycedrus L. subsp. oxycedrus, subsp. badia (H. Gay) Debeaux, and subsp. macrocarpa (Sibth. \& Sm.) Ball. J. Ess. Oil. Res. 11, 167-172.

Adams, R., 2007. Identification of Essential Oil Components by Gas Chromatography/Mass Spectrometry, $4^{\text {th }}$ Ed. Allured Publishing Corporation, IL, USA, pp. 9-31.

Angioni, A., Barra, A., Russo, M.T., Coroneo, V., Dessi, S., Cabras, P., 2003. Chemical composition of the essential oils of Juniperus from ripe and unripe berries and leaves and their antimicrobial activity. Journal of Agricultural and Food Chemistry. 51 (10), 3073-3078.

Athanassiou, C.G., Kavallieratos, N.G., Evergetis, E., Katsoula, A.M., Haroutounian, S.A., 2013. Insecticidal Efficacy of Silica Gel With Juniperus oxycedrus ssp. oxycedrus (Pinales: Cupressaceae) Essential Oil Against Sitophilus oryzae (Coleoptera: Curculionidae) and Tribolium confusum (Coleoptera: Tenebrionidae). Journal of Economic Entomology. 106 (4), 1902-1910.

Boti, J.B., Bighelli, A., Cavaleiro, C., Salgueiro, L., Casanova, J., 2006. Chemical variability of Juniperus oxycedrus ssp. oxycedrus berry and leaf oils from Corsica, analysed by combination of GC, GC-MS and ${ }^{13} \mathrm{C}-\mathrm{NMR}$. Flavour and Fragrance Journal. 21 (2), 268-273.

Cavaleiro, C., Pinto, E., Gonçalves, M.J., Salgueiro, L., 2006. Antifungal activity of Juniperus essential oils against dermatophyte, Aspergillus and Candida strains. Journal of Applied Microbiology. 100 (6), 1333-1338.

Derwich, E., Benziane, Z., Taouli, R., Senhaji, O., Touzani, M., 2010. A comparative study of the chemical composition of the leaves volatile oil of Juniperus phoenicea and Junipeus oxycedrus. Middle-East J. Sci. Res. 5 (5), 416-424.

Derwich, E., Chabir, R., 2011. Identification of the volatile constituents of the essential oil of Juniperus oxycedrus (Cupressaceae) from the north centre region of Morocco. Asian J Pharm Clin Res. 4 (1), 50-54.

Dob, T., Dahmane, D., Chelghoum, C., 2006. Essential oil composition of Juniperus oxycedrus growing in Algeria. Pharmaceutical Biology. 44 (1), 1-6.
Ismail, A., Lamia, H., Mohsen, H., Bassem, J., 2011. Chemical composition of Juniperus oxycedrus L. subsp. macrocarpa essential oil and study of their herbicidal effects on germination and seedling growth of weeds. Asian J. App. Sci. 4 (8), 771-779.

Lamnauer, D., 2005. A Guide to Medicinal Plants in North Africa; IUCN Centre for Mediterranean Cooperation Malaga, pp.157-158.

Loizzo, M.R., Saab, A.M., Tundis, R., Statti, G.A., Menichini, F., Lampronti, I., Gambari, R., Cinatl, J., Doerr, H.W., 2008. Phytochemical analysis and in vitro antiviral activities of the essential oils of seven Lebanon species. Chen Biodivers.5 (3), 461-470.

Medini, H., Elaissi, A., Khouja, M.L., Chraief, I., Farhat, F., Hammami, M., Chemli, R., Harzallah-Skhiri, F., 2010. Leaf essential oil of Juniperus oxycedrus L. (Cupressaceae) harvested in northern Tunisia: composition and intra-specific variability. Chem Biodivers. 7 (5), 1254-1266.

Medini, H., Elaissi, A., Khouja, M.L., Piras, A., Porcedda, S., Falconieri, D., Marongiu, Farhat, F., Chemli, R., 2012. Chemical composition of the essential oils of the berries of Juniperus oxycedrus L. ssp. rufescens (L. K.) and Juniperus oxycedrus L. ssp. macrocarpa (S. \& m.) Ball. and their antioxidant activities. Natural Product Research. 26 (9), 810-820.

Micevski, K., 1985. Flora na R. Makedonija. $1^{\text {st }}$ Ed. Makedonska Akademija na Naukite i Umetnostite, Skopje. pp. 81-84.

Salido, S., Altarejos, J., Nogueras, M., Sánchez, A., Pannecouque, C., Witvrouw, M., De Clercq, E., 2002. Chemical studies of essential oils of Juniperus oxycedrus ssp. Badia. Journal Of Ethnopharmacology. 81, 129-134.

Stassi, V., Verykokidou, E., Loukis, A., Harvala, C., Philianos, S., 1996. The antimicrobial activity of the essential oils of four Juniperus species growing wild in Greece. Flavour and Fragrance Journal. 11(1), 71-74.

Stassi, V., Verykokidou, E., Loukis, A., Harvala, A., Philianos, S., 1995. Essential Oil of Juniperus oxycedrus L. subsp. macrocarpa (Sm.) Ball.. Journal of Essential Oil Research. 7 (6), 675-676.

Velasco-Negueruela, A., Perez-Alonso, M.J., Pala-Paul, J., Inigo, A., Cervera, M., Lopez, G., 2003. Essential oil analysis of the leaves and berries of Juniperus oxycedrus L. subsp. badia (H. Gay) Deneaux. Botanica Complutensis. 27, 147-154.

Tumen, I., Suntar, I., Keles, H., Akkol, E.K., 2012. A Therapeutic Approach for Wound Healing by Using Essential Oils of Cupressus and Juniperus Species Growing in Turkey. Evidence Based Complementary and Alternative Medicine, Article ID 728281. 
Резиме

\title{
Хемиски состав и антимикробна активност на етерично масло од бобинки од диворастечка црвена смрека Juniperus oxycedrus L. (Cupressaceae) од Р. Македонија
}

\author{
Флореша Села ${ }^{1}$, Марија Карапанџова ${ }^{1 *}$, Ѓше Стефков ${ }^{1}$, Ивана Цветковиќ ${ }^{1}$, \\ Елена Трајковска-Докиќ ${ }^{2}$ Ана Кафтанџиева ${ }^{2}$, Светлана Кулеванова ${ }^{1}$

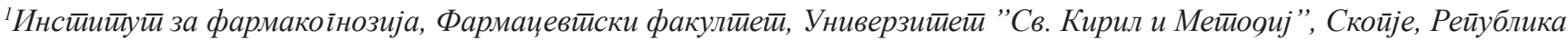 \\ Макеоонија

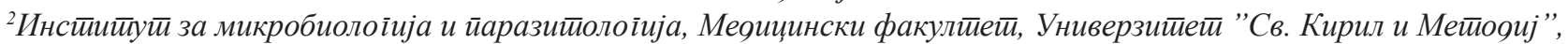 \\ Скойје, Рейублика Макеоонија
}

Клучни зборови: Juniperus oxycedrus, етерично масло од бобинки, состав на етерично масло, GC/FID/MS, антимикробна активност.

Хемискиот состав и антимикробната активност се испитувани на 2 различни примероци на етерично масло од бобинки од диворастечкиот Juniperus oxycedrus L. (Cupressaceae) од Република Македонија. Co GC/FID/MS анализа, идентификувани се 100 компоненти и истите сочинуваат 96,00-98,95\% од маслото. Најзастапените компоненти во маслото се $\alpha$-пинен (22,54-27,12 $\%)$, мирцен (11,26-15,13\%) и лимонен (2,78-18,06 \%). Антимикробната активност на етеричните масла е испитувана со диск дифузиона и диск дилуциона метода на 16 бактериски изолати на Грам позитивни и Грам негативни бактерии и еден изолат на габата Candida albicans. Најголема осетливост на дејството на маслата покажа бактеријата Haemophilus influenzae (MIC=125 $\mu 1 /$ $\mathrm{ml}$ ). Етеричните масла покажаа умерена антимикробна активност кон Streptococcus pneumoniae, Staphylococcus aureus, Streptococcus agalactiae, Streptococcus pyogenes, Corynebacterium spp., Escherichia coli и Campilobacter jejuni (MIC> $500 \mu 1 / \mathrm{ml})$. Етеричните масла не покажаа активност кон Candida albicans, Staphylococcus epidermidis, Acinetobacter spp., Salmonella enteritidis, Shigella flexnery, Klebsiella pneumonia, Pseudomonas aeruginosa, Enterococcus и Proteus mirabilis. 